\title{
REFLECTION
}

\section{Engaging the Public with and Preserving the History of Texas's First Public Historically Black University}

\author{
Marco Robinson ${ }^{1}$ and Phyllis Earles ${ }^{2}$ \\ 1 Division of Social Work, Behavioral, and Political Sciences, Prairie View A\&M University, Prairie View, Texas, US \\ 2 Special Collections and Archives, Prairie View A\&M University, Prairie View, Texas, US \\ Corresponding author: Marco Robinson, PhD (mtrobinson@pvamu.edu)
}

\begin{abstract}
The silences and erasures surrounding the histories of historically black colleges and universities (HBCUs) in many instances are caused by limited technology, lack of financial resources, and, most importantly, institutional priorities. Many aspects of HBCUs' histories, particularly in the state of Texas, have been relegated to historical voids or are becoming endangered knowledge. These are the issues that jeopardize the long and rich history of Prairie View A\&M University (PVAMU), Texas's first public supported historically black university, which dates back to the post-Reconstruction and Jim Crow eras of American history. Emancipated blacks in Texas sought all avenues available to them to obtain an education, including establishing churches and schools. Freed people's efforts culminated in the creation of Alta Vista School for Colored Youth, which subsequently became PVAMU following several name changes. During the Jim Crow era, PVAMU served as the administrative home base for black education in the state of Texas, offered agricultural extension services to black farmers, and served as the central facility for black grade school athletics and extracurricular activities. Due to lack of personnel and resources, all of the archival collections that document this history are unprocessed and unavailable to the public. This article considers the collaborative efforts of the history faculty and the Special Collections and Archives (SCAD) staff at PVAMU to bring light to this important history through preservation projects, public programming and student engagement activities. Additionally, the article uses endangered archival materials from PVAMU's Special Collections to explore the history of this important institution of higher education.
\end{abstract}

Keywords: Historically Black Colleges and Universities; Prairie View A\&M University; historic preservation; archival studies; digitization; oral history; service learning; community engagement; collaboration; Texas History; Black Texans

\section{Introduction}

The recent debut of the documentary Tell Them We Are Rising: The Story of Black Colleges and Universities (HBCUs) has stirred much discussion and brought light to the histories of institutions of higher education established for emancipated blacks in the United States following the Civil War. ${ }^{1}$ As the documentary shows, emancipated blacks joined forces with church-affiliated missionary societies and philanthropic organizations and began organizing schools all across the American South, including Texas. Historian Heather Williams argues that '[a]cquiring literacy in conjunction with freedom had the potential to open access to democratic political activity, and that in turn held a promise of enabling African Americans to participate in shaping the civil society in which they had hitherto been considered chattel' (2005: 69). In this political climate, Prairie View A\&M University (PVAMU), Texas's first public supported historically black college and university, was established during the late 1800s (See Figure 1).

\footnotetext{
${ }^{1}$ This film debuted on February 19, 2018 on Public Broadcast Station (PBS) in the US. The documentary chronicles the history of and circumstances surrounding the creation of historically black colleges and universities in the United States. The documentary is available online: http://www.pbs.org/independentlens/films/tell-them-we-are-rising/.
} 


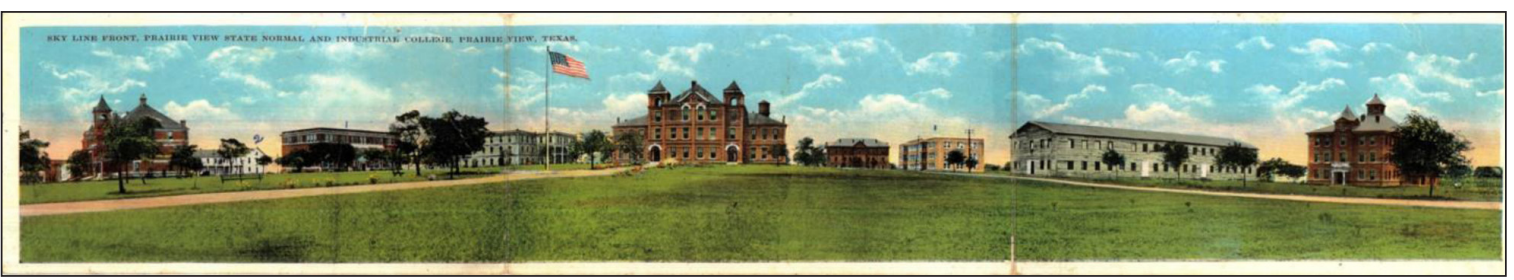

Figure 1: A skyline view of Prairie View State Normal and Industrial College, early 1900s. Courtesy of PVAMU's Special Collections and Archives Department.

The history of black colleges and universities in the US mirrors the country's longer struggle with Jim Crow segregation and centers the role of education in the fight for racial justice (Cantey and Bland 2013). Out of these turbulent circumstances, historically black colleges and universities were born. PVAMU's story is a fundamental part of the black experience in Texas, Texas educational history, and US educational history. PVAMU administrators, faculty and staff played a significant role in the fight for racial justice in Texas, the American South, and the country, working alongside organizations on the national stage. Thus, PVAMU's history is a significant piece of Americana and entails an important chapter in the American experience.

Currently, several of the signature archival collections housed by PVAMU are in dire need of being processed. Additional funding is needed to hire an audio digitization expert, and more space needs to be secured for storing the vast collections. This article highlights the efforts of the history faculty and PVAMU's Special Collections and Archives (SCAD) to document and preserve the Jim Crow-era history of PVAMU and to engage the public with the history of PVAMU. The history highlighted in this article covers significant events related to PVAMU's history during the segregation era. We examine the importance of PVAMU's Jim Crow-era history and the importance of efforts to preserve artifacts and documents, digitize photo collections, promote student engagement, and raise public awareness regarding this endangered history. The collaborative efforts of faculty and staff to save and record the history of their institution provides a model for other HBCUs to follow and brings light to the rich history of these often forgotten institutions of higher education.

\section{The Importance of PVAMU's Jim Crow-Era History in State, Regional, and National Contexts}

PVAMU was founded as Alta Vista College for Colored Youth by state legislative decree on August 14, 1876 (Nojeim and Jackson 2011). In the earlier part of 1876, William H. Holland, a black state representative from Waller County, Texas, sponsored legislation to create a state-supported college for black youth (See Figure 2). Unlike the church denomination and missionary society beginnings of many other HBCUs, Alta Vista College for Colored Youth was a satellite of the Agricultural and Mechanical College of Texas, which was to be the all-white state flagship institution of higher education (now known as Texas Agricultural and Mechanical University, located in College Station, Texas). ${ }^{2}$ According to historian George Ruble Woolfolk, the move to establish a state-supported educational institution for emancipated blacks coincided with the movement across the state of Texas for compulsory education and a statewide publicly supported education system (1962: 28). Historian James Anderson concludes that ' $\mathrm{f}$ ] ormer slaves were the first among native southerners to depart from the planters' ideology of education and society and to campaign for universal, state-supported public education' (1988: 4). Anderson further asserts, '[i]n their movement for universal schooling the ex-slaves welcomed and actively pursued the aid of Republican politicians, the Freedmen's Bureau, northern missionary societies, and the union army' (1988: 4). Representatives of the state legislature chose the Alta Vista Plantation (also known as the Kirby Plantation) in Waller County, Texas as the site to locate the school for black youths. ${ }^{3}$

L. W. Minor, a native Mississippian, was chosen as the first principal of Alta Vista College for Colored Youth. ${ }^{4}$ The first eight students enrolled in the school on March 11, 1878. Initially, the school operated as a grade or normal school with aspirations of being a full-fledged college (Woolfolk 1962). However, the first fifty years of the school's existence were very challenging due to lack of funding, low enrollment and no legislative support. Ernest Anderson and Laurine Anderson, two brothers, were principals at the institution for the next fifteen years (Ernest served from 1879 to 1885 and Laurine from 1885 to 1895). Ernest died in office at the age thirty-five, and Laurine took over, bringing vitality to campus life by working to improve the instruction and living accommodations (Woolfolk 1962: 5) (See Figure 3).

\footnotetext{
${ }^{2}$ The fifteenth Legislature of Texas established the Agricultural and Mechanical College of Texas on August 14, 1876.

${ }^{3}$ A special committee was formed consisting of J. H. Raymond, Dr. Ashbel Smith, and J. D. Giddings to find a site to the school for youth. They chose the Kirby Plantation in Waller County, which at the time had a majority black population.

${ }^{4}$ The first administrative leaders of PVAMU were given the title of principal because they were subordinates of Thomas Garthwright, president of A\&M College; PVAMU was the satellite institution for blacks. Garthwright was also from Mississippi, which arguably was the connection between the two men.
} 


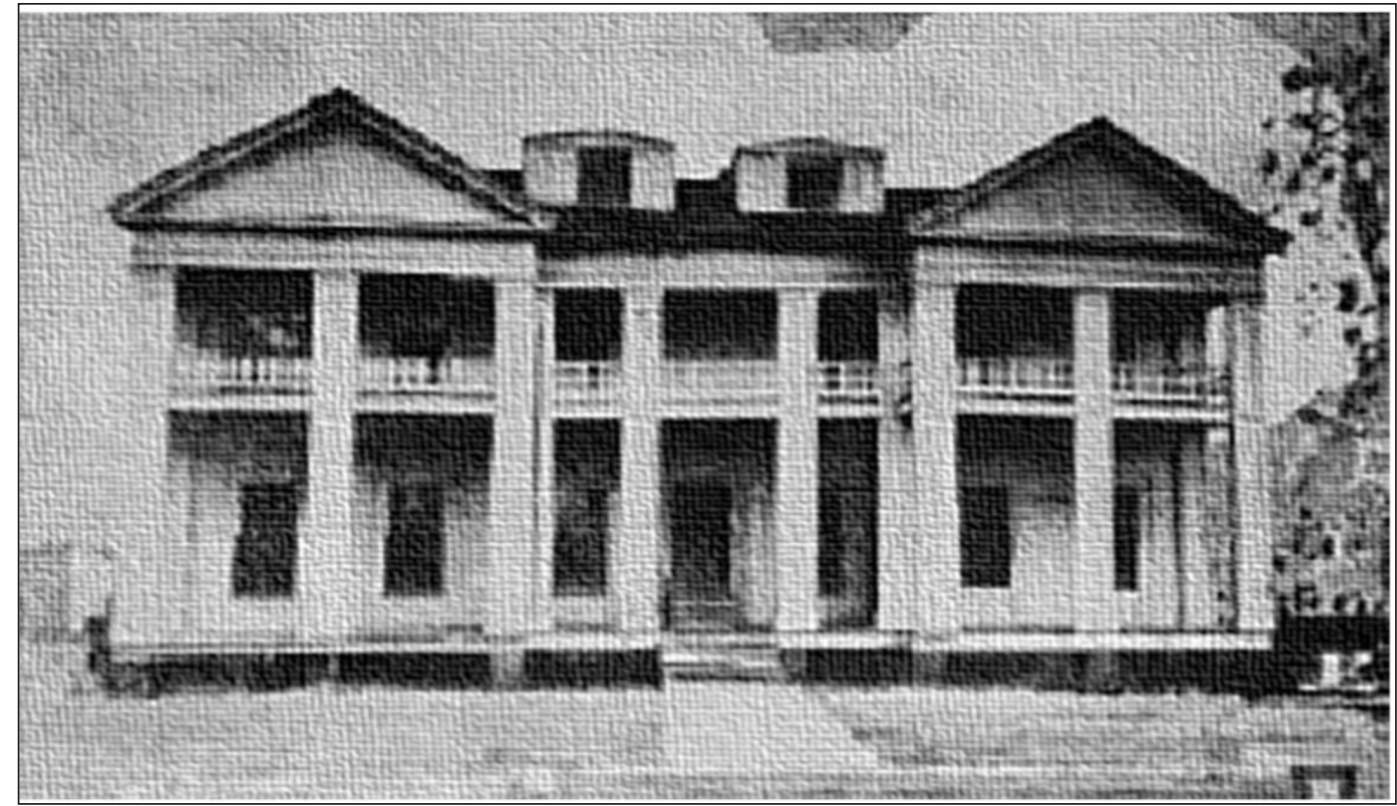

Figure 2: Kirby Hall, the first building on campus and the former main house of the Kirby Plantation. Courtesy of PVAMU's Special Collections and Archives Department.

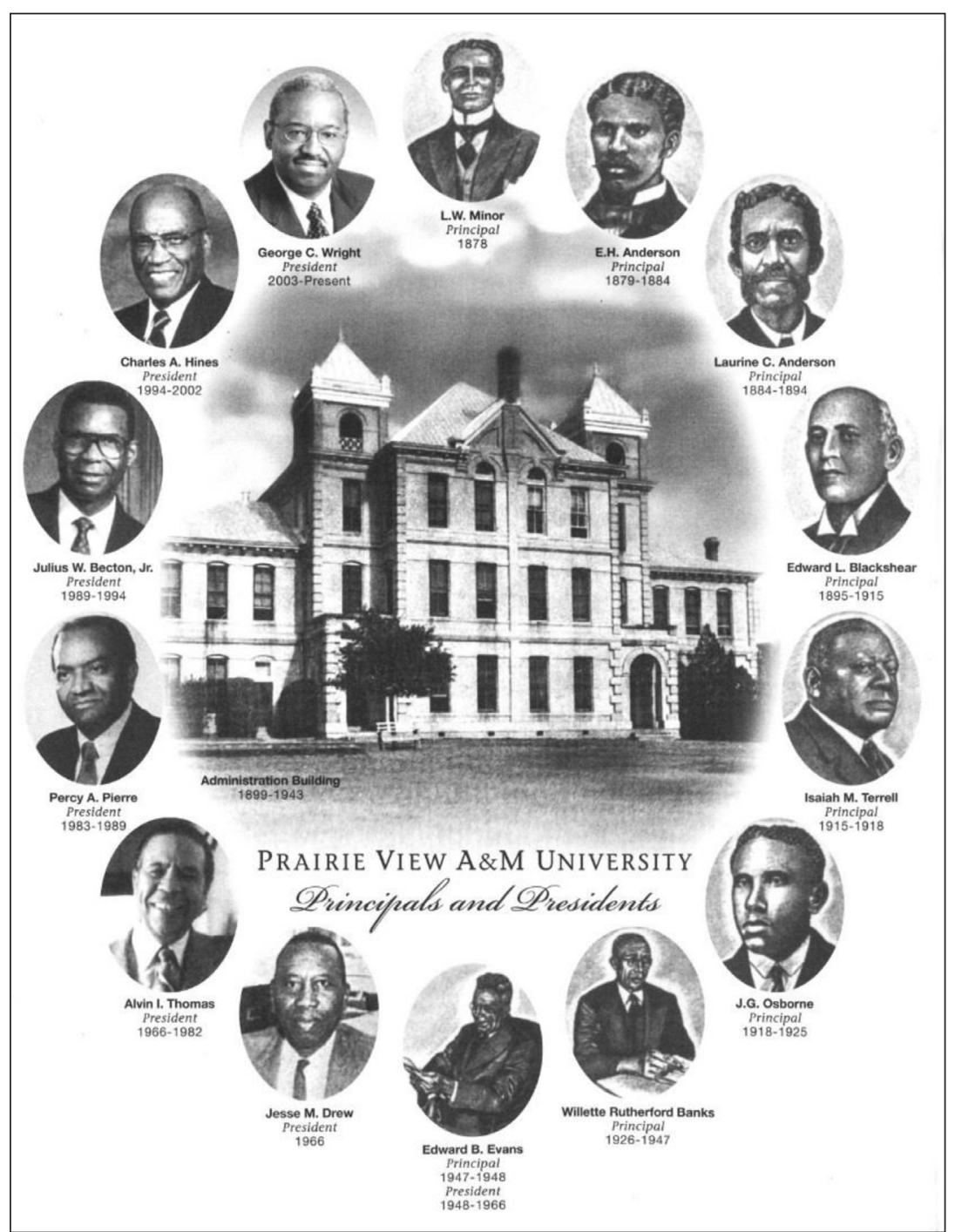

Figure 3: The principals and presidents of PVAMU up to 2016. Ruth Simmons, the current and first female president of the university, is not pictured. Courtesy of PVAMU's Special Collections and Archives Department. 
As the Age of Segregation loomed over the American South, the focus of black education went to industrial and vocational training. Booker T. Washington championed industrial education across the American South and was founder of the Tuskegee Institute. Edward Blackshear, president of PVAMU from 1895 to 1915 and close acquaintance of Booker T. Washington, shaped the programs to reflect this trend. Prairie View women were trained in the domestic sciences, while men were trained in a wide range of vocational trades, including agricultural sciences, automotive repair and carpentry (Woolfolk 1962: 30) (see Figures 4 and 5). This was

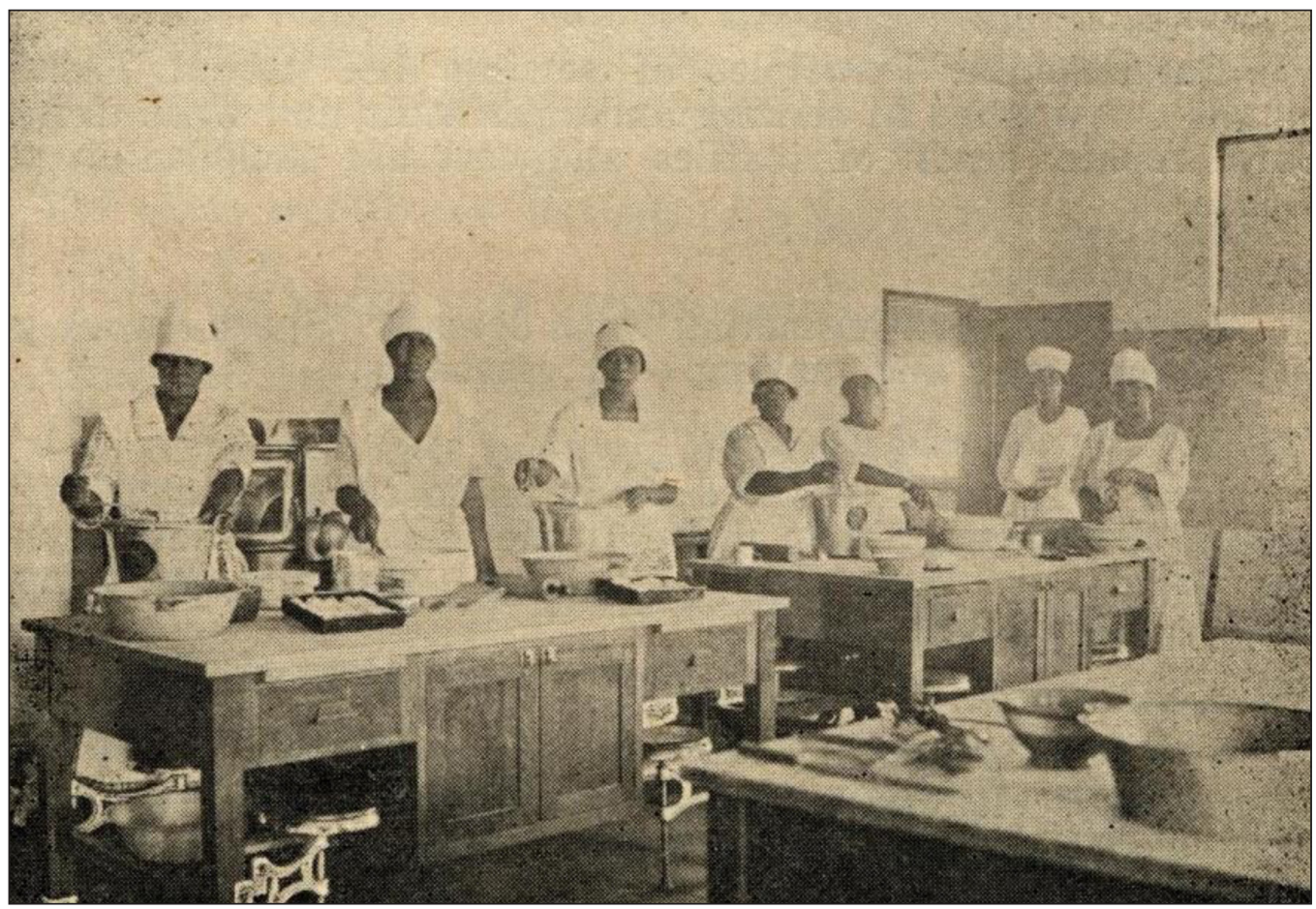

Figure 4: Female students in a domestic science class at PVAMU during the early 1900s. Courtesy of PVAMU's Special Collections and Archives Department.

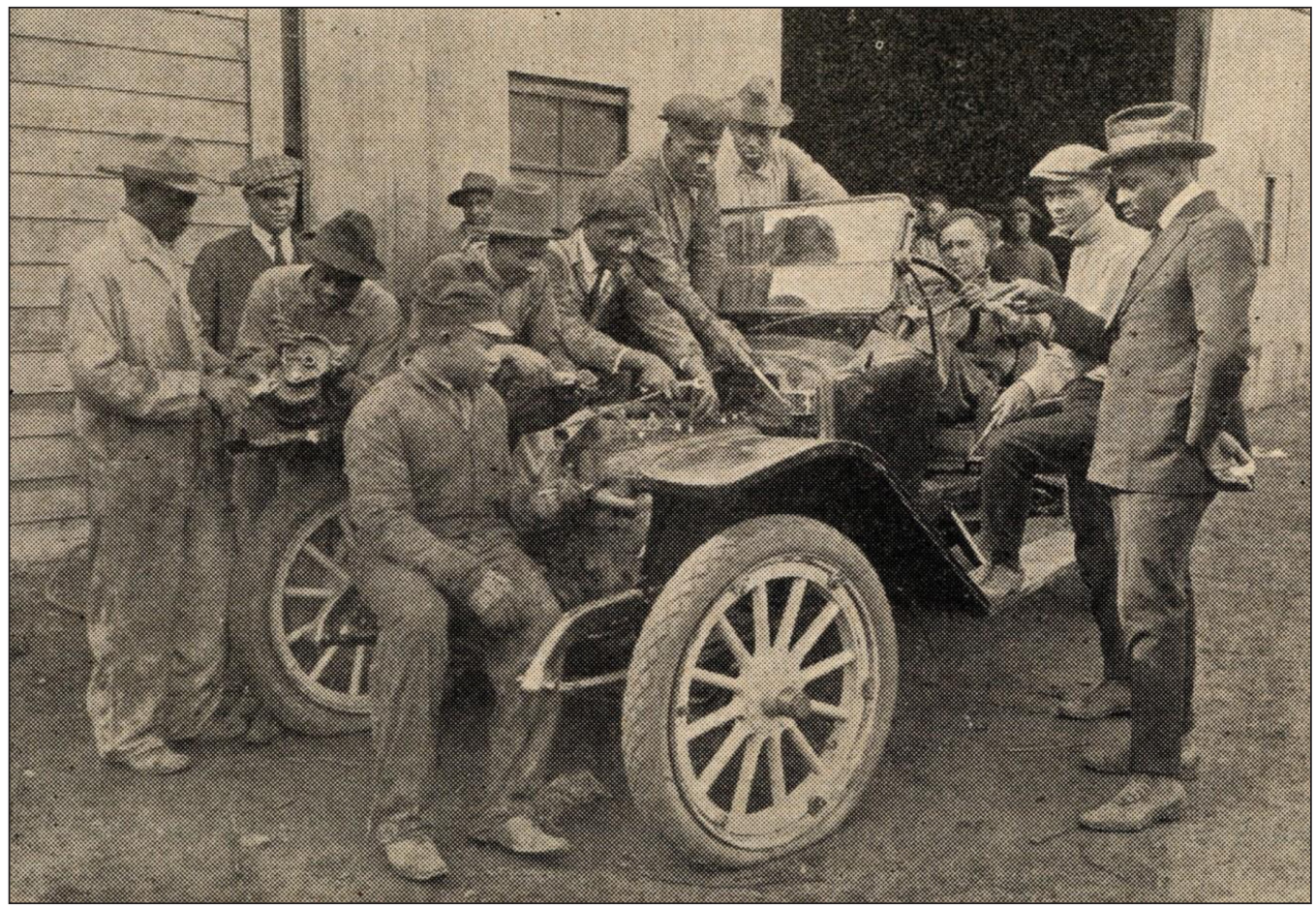

Figure 5: Male students participating in an auto mechanic demonstration at PVAMU during the early 1900s. Courtesy of PVAMU's Special Collections and Archives Department. 


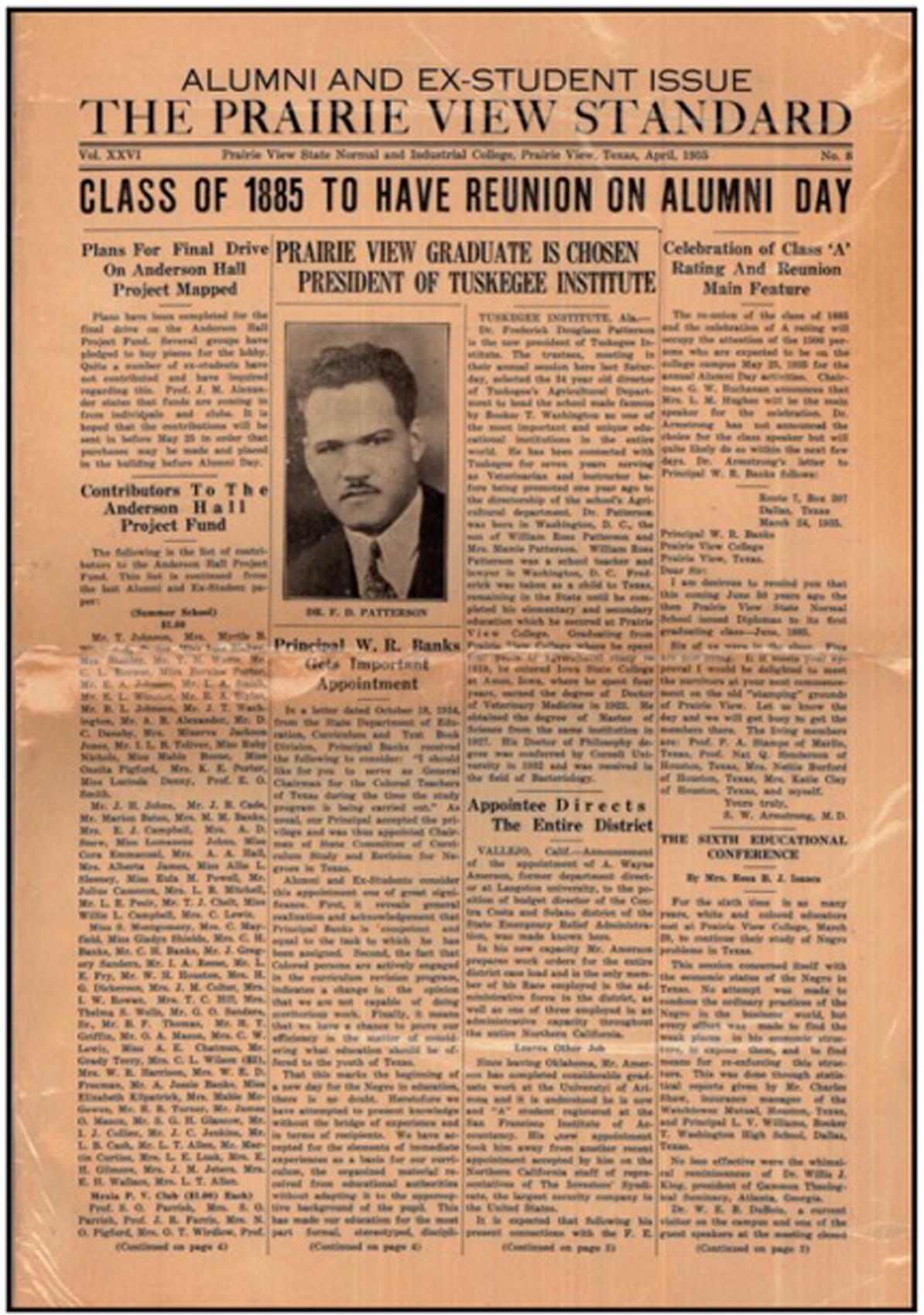

Figure 6: Article on Fredrick Patterson becoming president of Tuskegee University in the Prairie View Standard, April 1935. Courtesy of PVAMU's Special Collections and Archives Department.

a formative period in the school's history, which proved the institution's importance in teaching blacks in Texas and in the South. Many of PVAMU's students from this period-for example, Frederick Patterson-went on to be educators and leaders in their communities. Patterson became president of Tuskegee University and was the founder of the United Negro College Fund (see Figure 6).

Isiah Milligan (I. M.) Terrell became principal of PVAMU in 1915 and was instrumental in helping to establish the Colored Cooperative Extension Service (CES), which served blacks all across the state of Texas (Nojeim and Jackson 2011). The CES provided local farmers with training on agricultural techniques and instruction in recent technological farming advances, and demonstration agents were assigned to black communities by counties across Texas. During the Jim Crow era, PVAMU was the home base for blacks to receive instruction in the agricultural sciences. Due to the stringent state segregation laws, blacks were not offered the same services from white institutions. PVAMU stepped forward to support black farmers at a critical time in US history, when the country was exiting World War I and was close to entering a severe economic depression (see Figures 7 and 8). In addition, PVAMU served as the home administrative base for black public schools in Texas by hosting a yearly Negro Education Conference, which was initiated under 


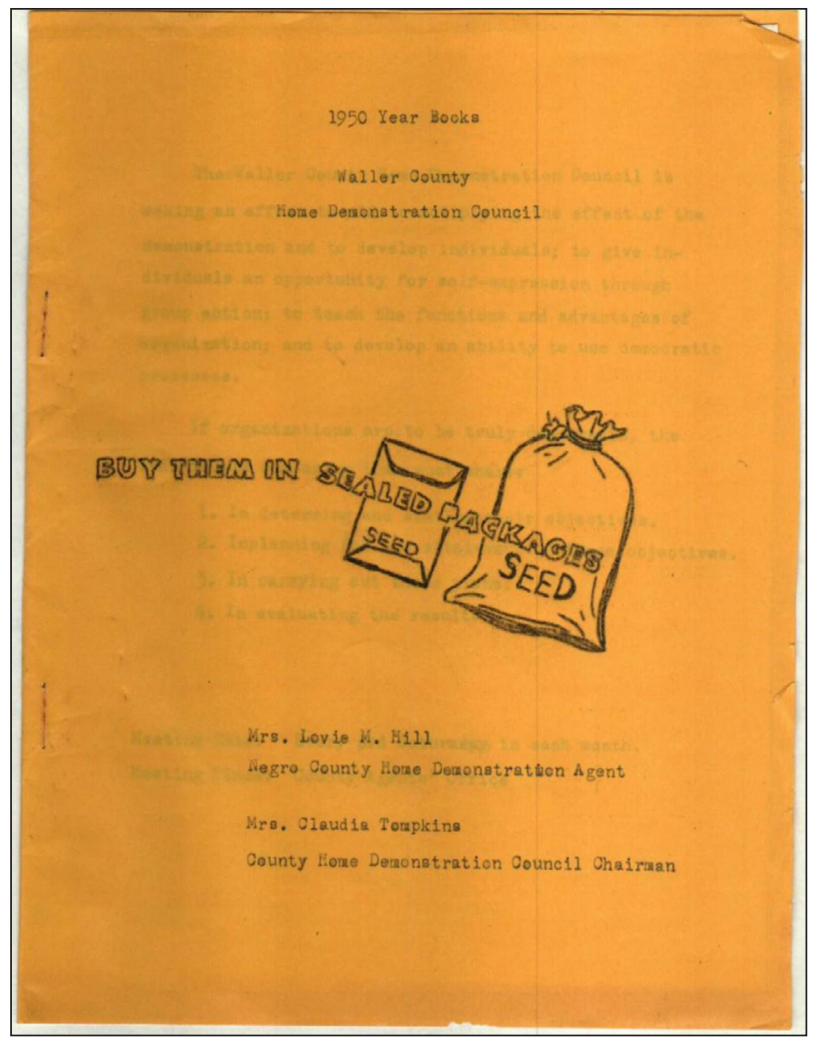

Figure 7: Agricultural Demonstration Yearbook about buying seeds, 1950. Courtesy of PVAMU's Special Collections and Archives Department, Agricultural Extension Collection.

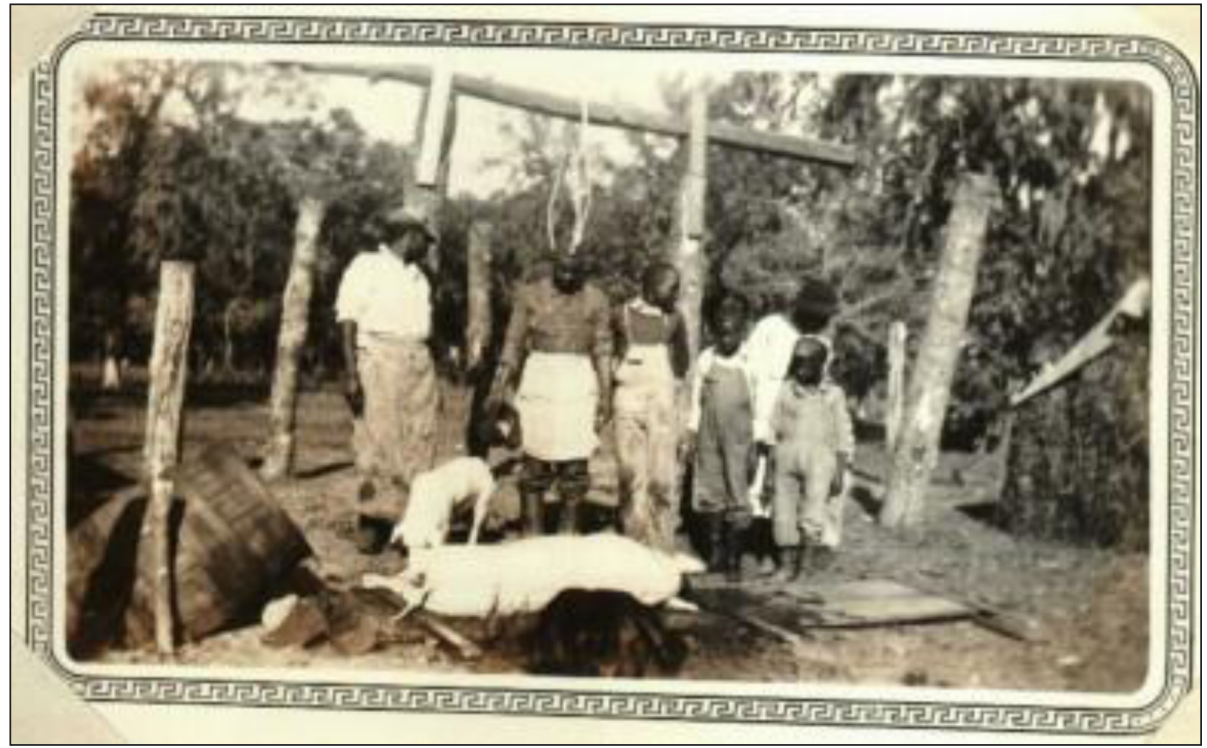

Figure 8: Photograph of a livestock management demonstration on butchering hogs, 1937. Courtesy of PVAMU's Special Collections and Archives Department, Agricultural Extension Collection.

the administration of Willette Rutherford Banks, principal from 1926 to 1946 (see Figure 9). The annual conference gatherings were used to discuss issues impacting black education and communities in Texas.

Nationally, PVAMU was the first HBCU assigned an Army ROTC cadet unit and a Navy ROTC unit. The Army ROTC unit was established directly after World War I, and the Navy unit was established during the early 1970s. Many of the cadets from the PVAMU ROTC units have gone on to become high-ranking officers in the United States military (Nojeim and Jackson 2011) (see Figure 10). In addition to producing valiant military servicemen and women, PVAMU served as the primary medical hub for the black community in Waller County during the Jim Crow era. PVAMU housed the only hospital for blacks in the immediate area, and the university hosted an annual meeting for black physicians from across the state 


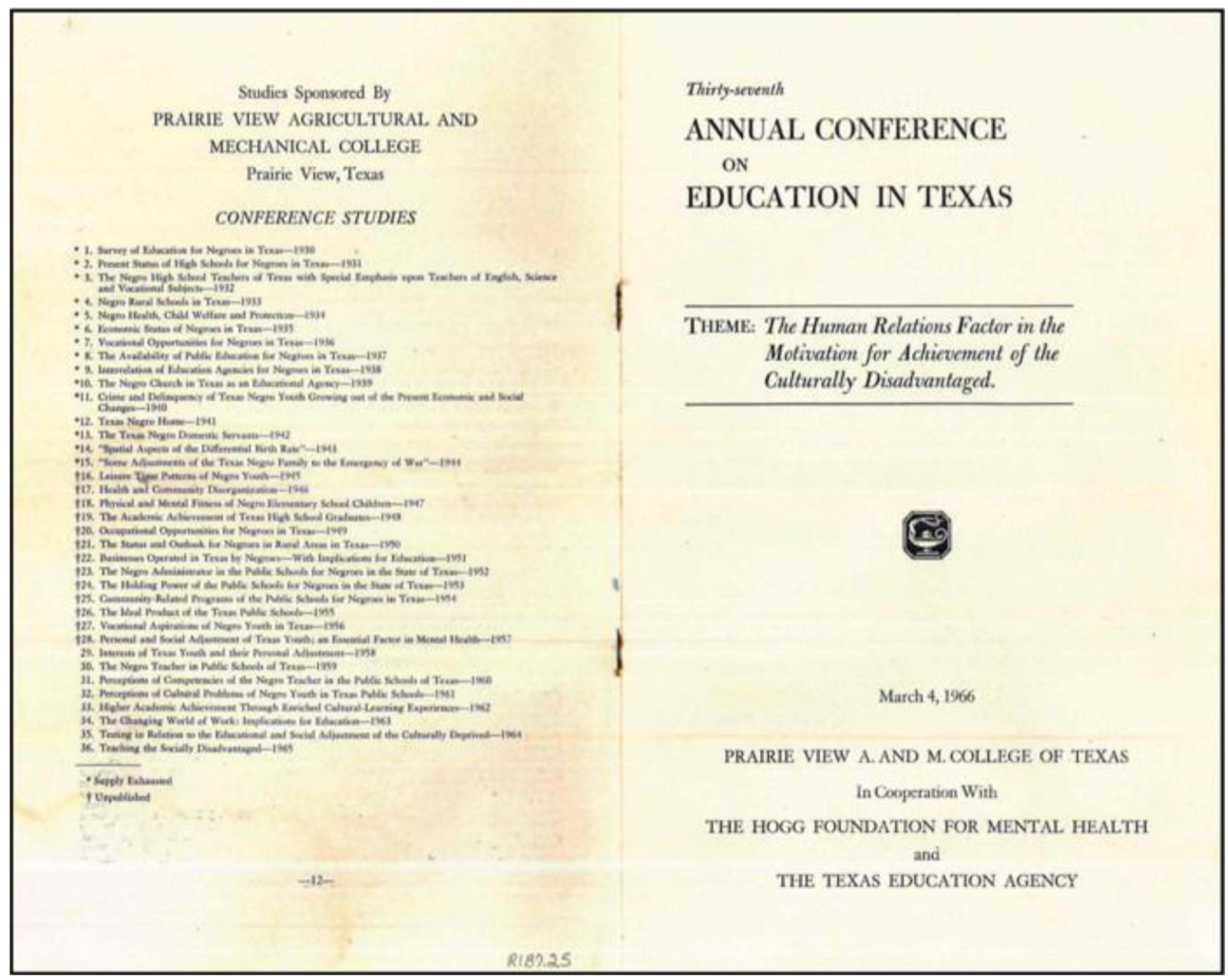

Figure 9: Program pamphlet for Annual Conference on Education in Texas, 1966. Courtesy of PVAMU's Special Collections and Archives Department, Annual Negro Education Conference Collection.

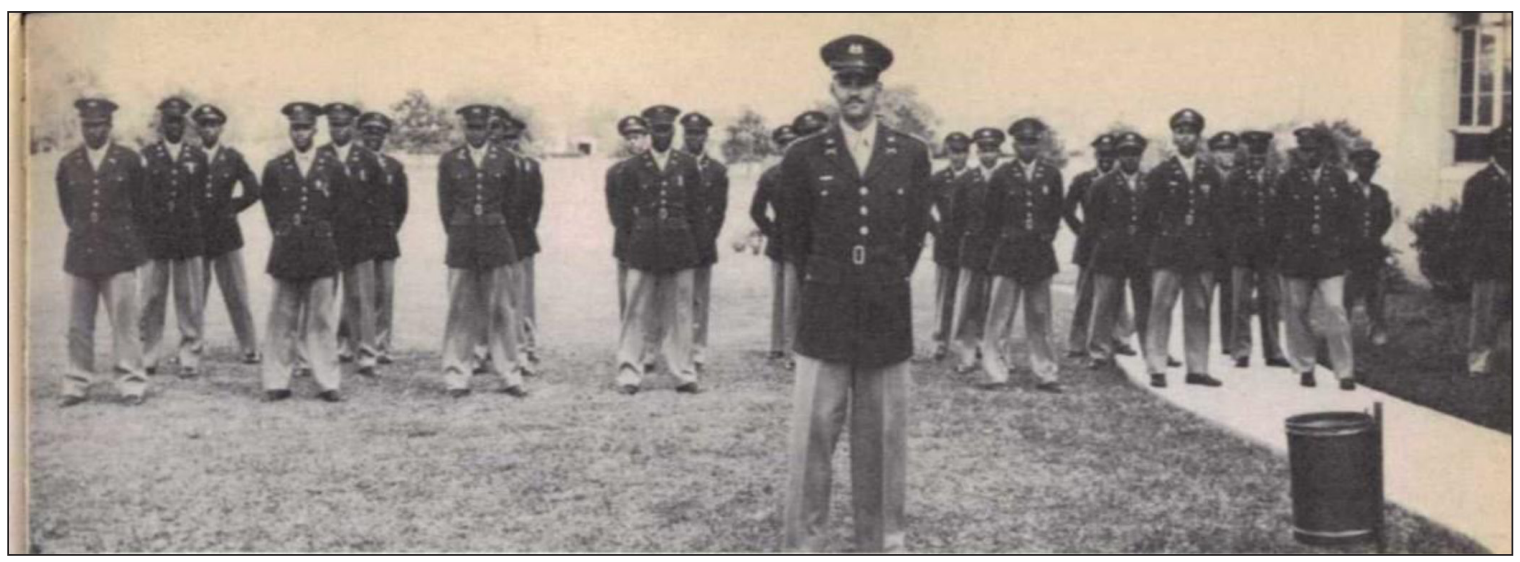

Figure 10: Army ROTC cadets standing at attention, c. 1950. Courtesy of PVAMU's Special Collections and Archives Department, ROTC Collection.

of Texas during the early 1900s (see Figures 11 and 12). At state, regional, and national levels, PVAMU administrators, faculty, staff and students had a profound impact on American life and culture during the first half of the 1900s.

\section{Preservation Efforts and Student Engagement}

The Jim Crow Collections held within PVAMU's Special Collections and Archives are endangered due to a lack of funding to fully process the collections, the absence of an expert on staff to digitize the audio recordings of the collections, and limited space to house the collections. Paper and audio materials are decaying and are at risk of never being revealed to the public. PVAMU's Special Collections and Archives Department (SCAD), housed in the fifth floor of the main campus library, has limited space for its more than 1,000 rare books, more than 20 manuscript collections, and more than 25,000 photographs. SCAD has two full-time staff members, including the lead archivist, who are assisted by several part-time student workers. However, the labor and expertise needed to fully process these collections are more than the SCAD staff can 


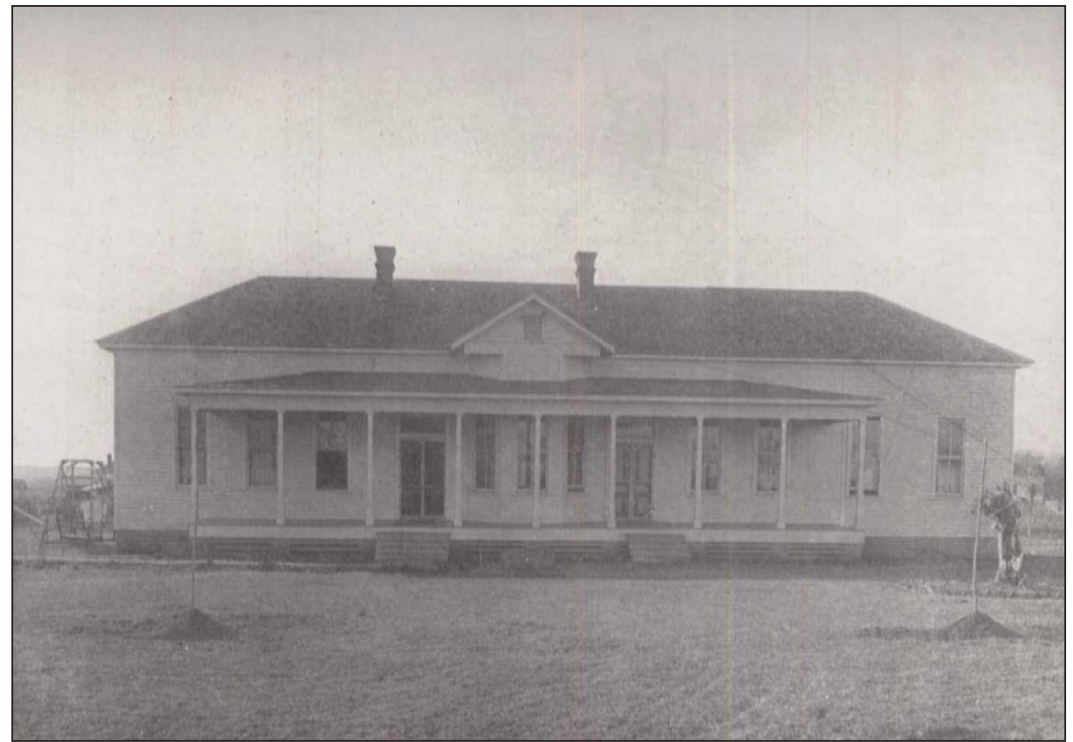

Figure 11: The campus hospital, 1917. Courtesy of PVAMU's Special Collections and Archives Department.

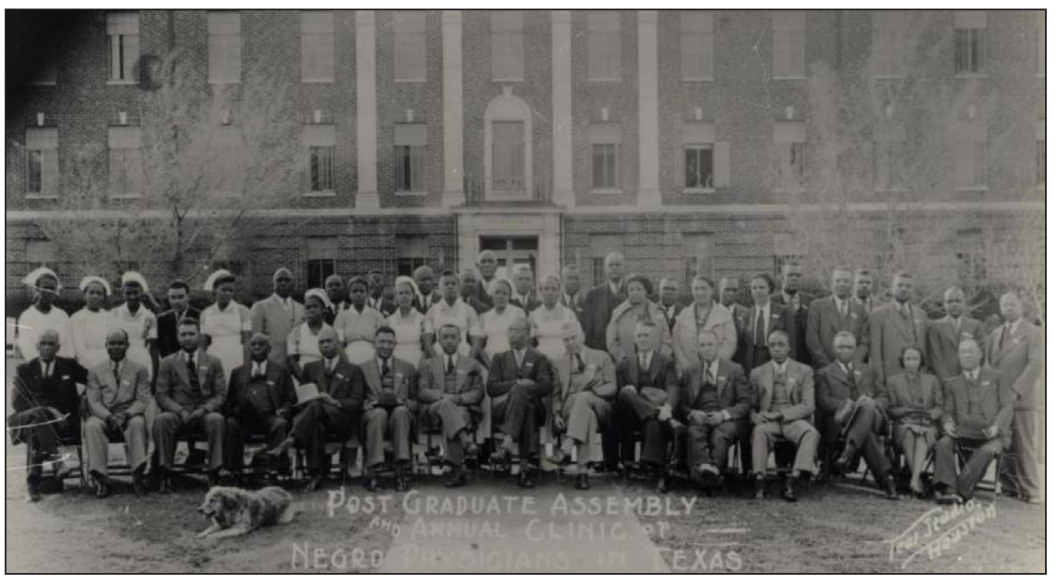

Figure 12: Picture of the Post-Graduate Assembly of Negro Physicians, early 1900s. Courtesy of PVAMU's Special Collections and Archives Department.

handle. As of the summers of 2017 and 2018, the staff had made modest progress towards making the Jim Crow Collections available to the public.

The collections still need to be processed, digitized, and described in an online database. In addition, some materials require special conservation and preservation attention. For instance, the Negro Education Collection has rare and vulnerable magnetic audio tapes that SCAD does not have the equipment, or funding, to digitize. During the fall of 2016, SCAD staff met with and solicited assistance from PVAMU's history faculty to assist with preserving these endangered items and to create a joint service-learning program where students would gain a meaningful experience through doing archival work and engaging in historic preservation. The initial meetings led to the creation of service-learning components in two history research courses to involve students in the preservation of several archival collections related to the school's history. ${ }^{5}$

By linking theory with practice and classrooms with communities, service-learning provides real-world exposure and engagement with meaningful local and global issues through concrete and ameliorative practices (Butin 2006). SCAD staff and history faculty agreed that the overall goals of the joint project would be to provide the students with a meaningful experience working within the realm of archival studies and historic preservation, to preserve the collections that needed the most attention, and to create programming that allowed the collections to be discussed and displayed for the public. Ultimately, faculty

\footnotetext{
${ }^{5}$ The history courses were Introduction to Historical Methods of Research (sophomore level) and the History Senior Capstone Research Course. The Introduction to Historical Methods course is open to all students and has no prerequisites. The two students who participated in the research symposium worked in the archives through funding provided by the Student Research Opportunities Program (SROP) (funded by the University).
} 
and staff wanted student participants to gain tangible skills that they could apply to jobs in the public and private sectors of education and public history, or to advanced research at the graduate level. As a result, the service-learning component of the courses focused on the digitization and cataloging of the George Ruble Woolfolk Collection, the Agricultural Extension Collection, and the Negro Education Conference records. The collections chosen were most relevant to the students' in-class research projects. The faculty and staff also agreed to add an oral history collection component to the project.

In order for student participants to have a thorough understanding of archival procedures and historic preservation, SCAD staff and history faculty conducted several training sessions. The subjects of the training sessions ranged from how to properly handle fragile documents and scan items to how to catalogue the items and make finding aids. Additionally, students were trained in conducting oral histories. In a Historical Methods research course, the instructor introduced the oral history component of the service-learning project, which entailed having students interview former PVAMU students who lived during the Jim Crow era. All of the training sessions were conducted in accordance with the best practices suggested by the Society of American Archivists and the Oral History Association. During the sessions, the facilitators conveyed to the students the importance of following the outlined procedures to ensure that the materials were properly processed, signed and secured and that students were using the best practices for preserving historical items (see Figures 13-15).

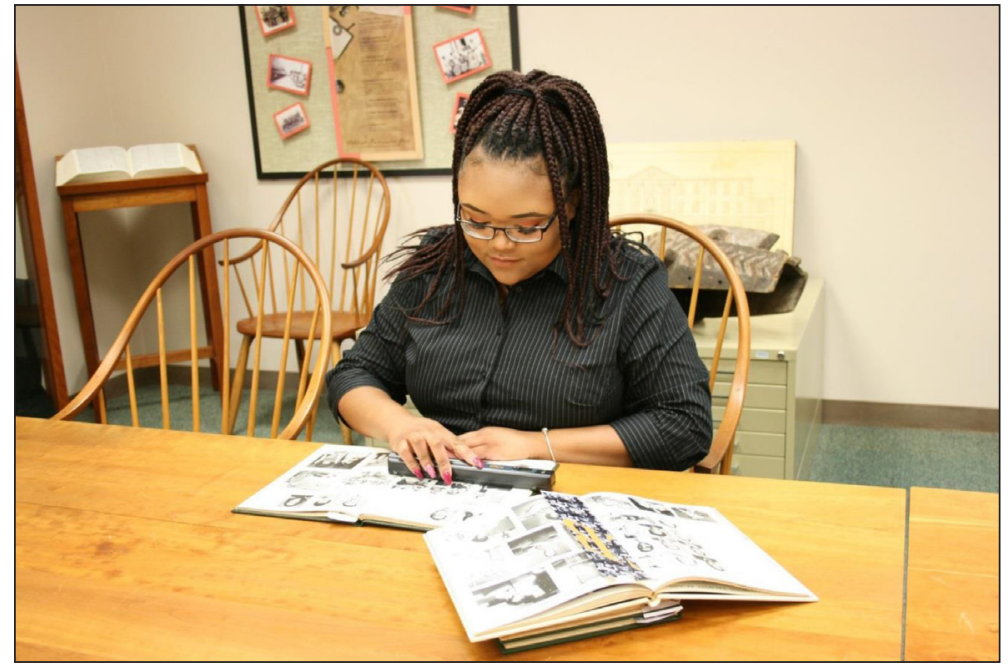

Figure 13: Chanel Williams, student participant, scanning items from a PVAMU yearbook for her research project, 2017. Courtesy of PVAMU's Special Collections and Archives Department. (The picture is displayed with the permission of the student).

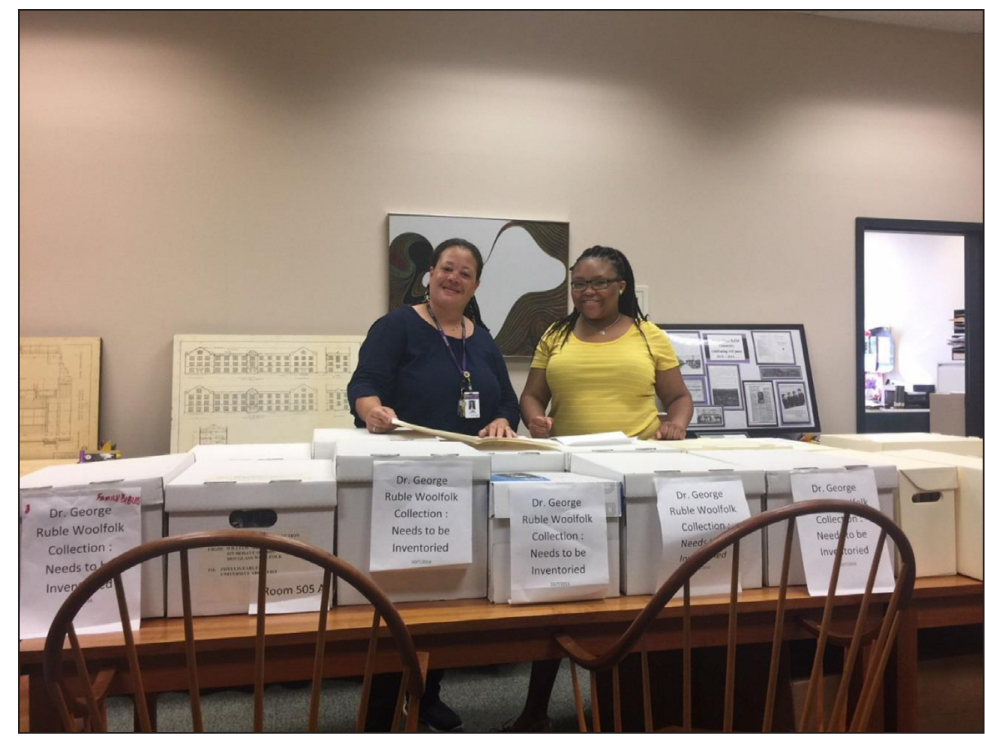

Figure 14: Lisa Stafford, PVAMU SCAD staff, and Chanel Williams, student participant, sorting through boxes that need to be inventoried, 2017. Courtesy of PVAMU's Special Collections and Archives Department. 


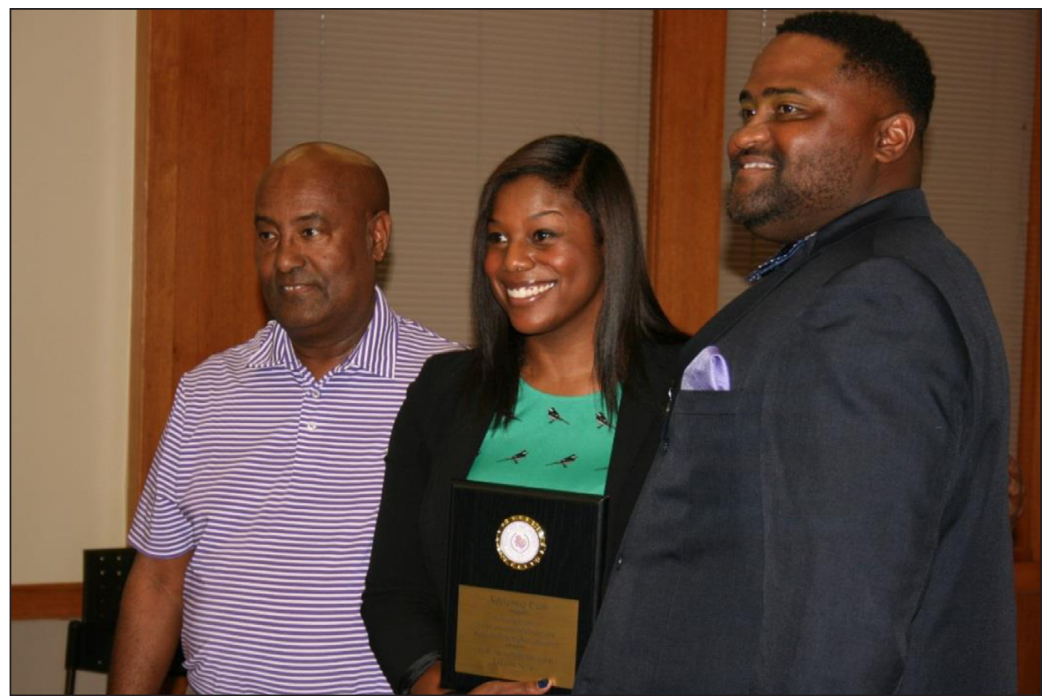

Figure 15: (Left to right) Dr. Walle Engedayehu, chair of the Division of Social Work, Behavioral, and Political Sciences; Adrienne Cain, assistant director of the Baylor University Institute for Oral History; and Dr. Marco Robinson, assistant professor of history, PVAMU, at a workshop on oral history in 2016. Courtesy of PVAMU's Special Collections and Archives Department.

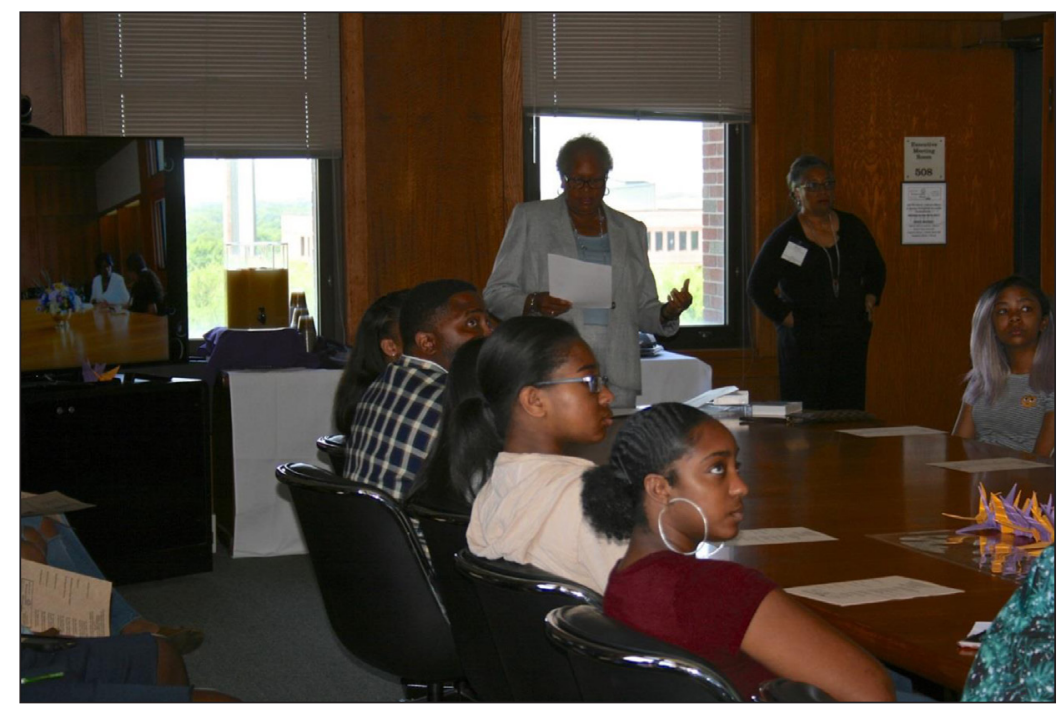

Figure 16: Dr. Lauretta Byars, vice president of Student Affairs, PVAMU, during the Archives Week Program, 2017. Courtesy of PVAMU's Special Collections and Archives Department.

\section{Programming and Raising Public Awareness}

A number of public panels and forums were held during the 2016-17 academic year to bring attention to the history of PVAMU and the efforts to preserve the school's rich past. The SCAD staff and history faculty team's goals for hosting these events were to provide information on PVAMU's history and to make the campus community and local community aware of the project underway. Additionally, the team wanted to solicit volunteers to expand the project, to gain candidates for interviews and to determine whether individuals who had rare materials wanted to loan them to be scanned or donate them to PVAMU. Most importantly, the team wanted to gain campus and community buy-in with the project and build a viable infra-structure of volunteers to ensure the project's longevity and sustainability. The events proved to be successful due to the number of individuals from the immediate community who volunteered to be interviewed, and the needs of the SCAD were brought to PVAMU administrators' attention. As a result, Dr. Lauretta Byars, former vice president of Student Affairs, became an active participant in the preservation effort (see Figure 16).

Overwhelmingly, the events were well attended by PVAMU's students and members of the local community in Prairie View. Also, several PVAMU alumni reached out to the team to loan and donate items to be added to the SCAD collections. In addition, two of our student participants did poster board presentations at a 


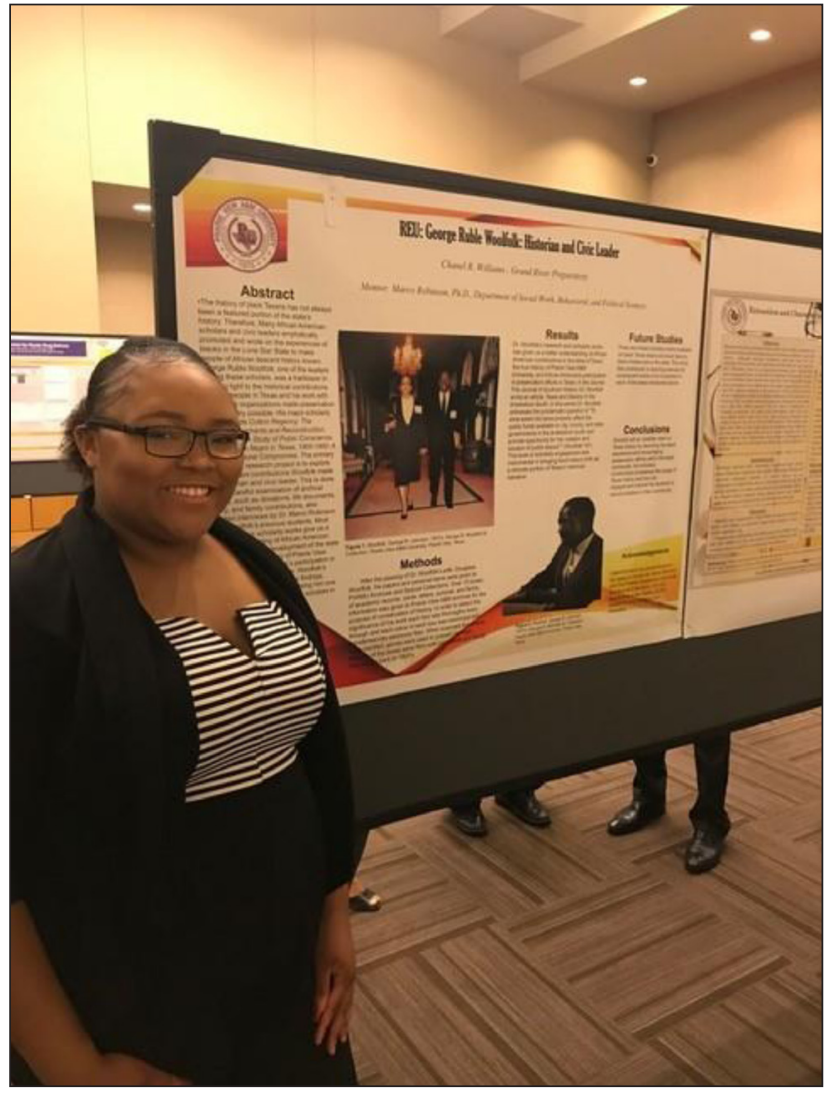

Figure 17: Chanel Williams, student participant, with her poster board presentation about the George R. Woolfolk Collection, 2017. Courtesy of PVAMU's Special Collections and Archives Department.

campus research symposium about the material from the Woolfolk and Negro Education archival collections that they processed and scanned, as well as their subsequent research (see Figure 17). The SCAD staff and Dr. Marco Robinson were able to reach all of the goals set for the public programming. However, they still faced a number of challenges in order to maintain the momentum of the project, which are addressed in the next section.

\section{Conclusion: Challenges of Preserving Endangered Collections and Knowledge at a HBCU}

As with all preservation projects, funding is imperative. The team is currently seeking internal and external funding to support the continued work of digitizing, cataloging and making finding aids for the PVAMU SCAD Jim Crow Collections. Server and cloud space are needed for storage and web-hosting of digital stories and video-recorded oral histories. The current space is not adequate and does not have the appropriate database functionality. Making sure that these technological resources are available will enable the team to be better suited to train the student participants. Over the past three semesters, over thirty students have worked on the project in some capacity, but it is important for the overall success of the project that we gain more faculty participation. One year into this project, we have realized the importance of networking and building relationships on campus with faculty and off campus with community members. In many cases, faculty are not aware of the various ways they can incorporate archival projects in their courses. To address this issue, the archival staff is providing informational sessions. Faculty participation is essential to making sure that this project continues for years to come.

For research teams interested in engaging in projects like this, it is important to form a good relationship with your university special collections and archives department. In addition, it is important to carefully plan the roles that students and the local community will play in the project so that each group gains from the experience. PVAMU students gained a wealth of experience, and the community participants were very appreciative that PVAMU's history was being preserved. Chanel Williams, a sophomore biology major, stated, 'I learned so much about the school's history and processing historical collections while working in archives' (Williams, personal interview with author, August 25, 2017). Mrs. Jemmie Poindexter, a local resident, explained, 'I wasn't aware that this preservation project was going on, but I am glad to assist in 


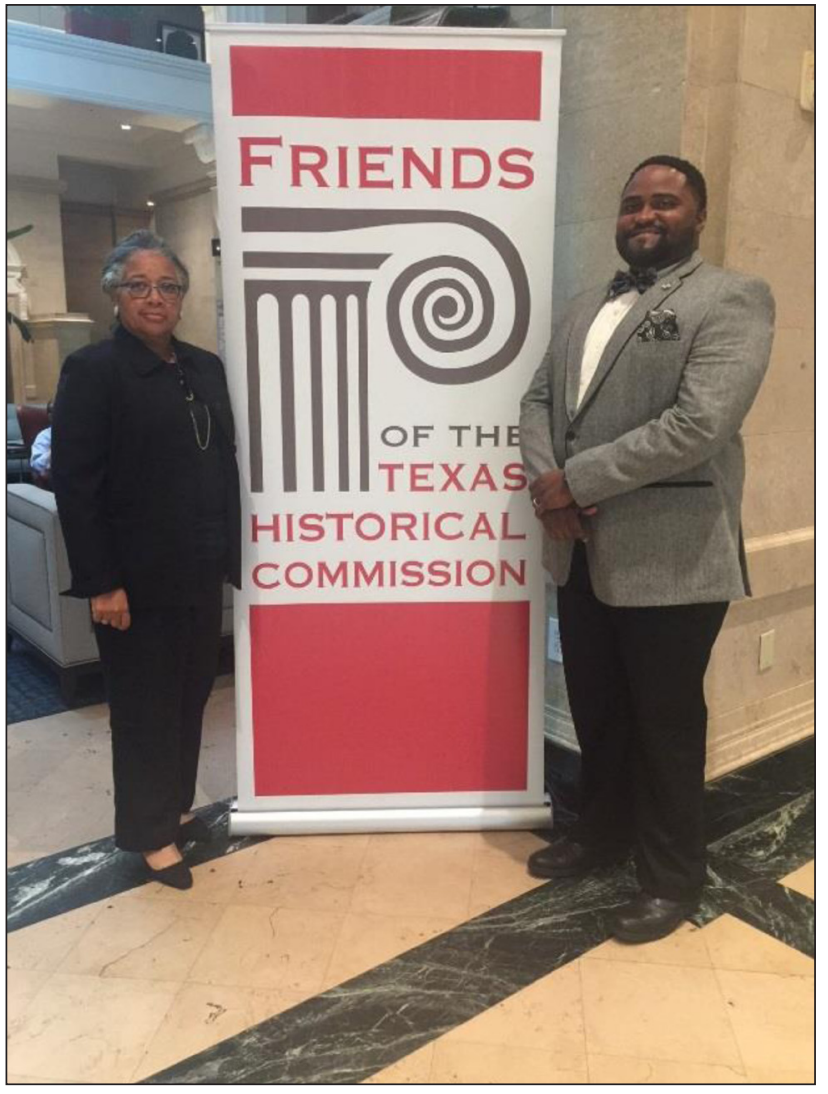

Figure 18: Phyllis Earles, university archivist at PVAMU, and Dr. Marco Robinson, assistant professor of history, PVAMU, at the Friends of the Texas Historical Commission Banquet, summer 2017. Courtesy of PVAMU's Special Collections and Archives Department.

any way that I can' (Poindexter, personal interview with author, July 15, 2017). The relationships formed from these interactions and partnerships with community members are important to a project's longevity and sustainability.

It is important that the home department or division of the project members provides the necessary support and resources to ensure the project's success. Finally, it is equally important to form relationships with local, state, and national preservation organizations. In many instances, through these organizations, teams can find the expertise and resources needed to make sure that their project reaches its goals (see Figure 18). The hard work of making sure that the endangered knowledge of a public HBCU's history does not become extinct is rewarding and preserves an important part of the American past.

\section{Competing Interests}

The authors of this work attest to the accuracy and authenticity of the information used to compose this work. Further, the authors received no support from any organization for this submitted work and have no financial relationships with any organizations that might have an interest in financial gain from the submitted work.

\section{References}

Anderson, James. 1988. The Education of Blacks in the South, 1860-1935. Chapel Hill: University of North Carolina Press. DOI: https://doi.org/10.5149/uncp/9780807842218

Butin, Dan. 2006. "Introduction." In "Future Directions for Service Learning in Higher Education." Dan Butin (ed.), International Journal of Teaching and Learning in Higher Education, Special issue, 18(1): 1-4.

Cantey, Nia Imani, Robert Bland, LaKerri R. Mack, and Danielle Joy-Davis. 2013. "Historically Black Colleges and Universities: Sustaining a Culture of Excellence in the Twenty-First Century." Journal of African American Studies, 17(2): 142-53. DOI: https://doi.org/10.1007/s12111-011-9191-0

Nojeim, Michael, and Frank Jackson. 2011. Down that Road: A Pictorial History of Prairie View A\&M University. Virginia Beach, VA: Donning Company Publishers. 
Williams, Heather. 2005. Self-Taught: African American Education in Slavery and Freedom. Chapel Hill: University of North Carolina Press. DOI: https://doi.org/10.1111/j.1748-5959.2007.00120.x Woolfolk, George. 1962. Prairie View: A Study in Public Conscience, 1878-1946. New York: Pageant Press.

How to cite this article: Robinson, Marco, and Phyllis Earles. 2018. Engaging the Public with and Preserving the History of Texas's First Public Historically Black University. KULA: knowledge creation, dissemination, and preservation studies 2(1): 24. DOl: https://doi.org/10.5334/kula.33

Submitted: 12 March $2018 \quad$ Accepted: 20 August $2018 \quad$ Published: 29 November 2018

Copyright: (c) 2018 The Author(s). This is an open-access article distributed under the terms of the Creative Commons Attribution 4.0 International License (CC-BY 4.0), which permits unrestricted use, distribution, and reproduction in any medium, provided the original author and source are credited. See http://creativecommons.org/ licenses/by/4.0\%. 